Tạp chí Khoa học và Công nghệ biển T11 (2011). Số 1. Tr 43 - 55

\title{
VAI TRÒ CỦA RÙNNG NGẬP MẶN LÀM GIẢM SÓNG BÃO TẠI KHU VỰC ĐẠI HợP (KIẾN THỤY, HẢI PHÒNG)
}

\author{
VŨ ĐOÀN THÁI
}

\section{Đại học Hải Phòng}

\begin{abstract}
Tóm tắt: Rùng ngập mặn tại xã Đại Hợp (Kiến Thuy, Hải Phòng) khi khảo sát có độ tuổi 5- 6 năm, được trồng tù 1999 - 2000. Rùng nằm sát đê biển, có chiều rộng 670m gồm hai loài bần chua (Sonneratia caseolaris (L.) Engl) và trang (Kandelia obovata Shuen Liu \& Gong). Cây bần chua có chiều cao trung bình $459 \mathrm{~cm}$; đuoòng kính thân 149,5 mm; mật độ 1351 cây/ha và tỷ lẹ che phủ là 93\%. Cây trang có chiều cao trung bình 165,5 cm; đường kính thân 90,6 mm; mật độ 16100 cây/ha và độ che phủ 92\%.

Con bão số 2 ngày 31/7/ 2005 đổ bộ vào khu vưc nghiên cứu tạo nên sóng phía truớc khoảng 1,0 - 1,5 m, năng luợng sóng bão trung bình $212.306 \mathrm{~N} / \mathrm{m}^{2}$. Sau khi vuọt qua rùng ngập mặn vào sát đê biển, độ cao sóng bão giảm xuống chỉ còn $0,2 \mathrm{~m}-0,32 \mathrm{~m}$, năng luợng sóng trung bình $9.158 \mathrm{~N} / \mathrm{m}^{2}$, với hệ số suy giảm sóng 75 - 83\%, trung bình 79\%. Ngoài tác động giảm sóng, rùng ngập mặn còn cản các gờ cát bùn do sóng tạo nên và đẩy vào bò̀. Các gò̀ cát bùn này rộng $35-40 \mathrm{~cm}$, độ cao $35 \mathrm{~cm}$ lấn sâu $55-60 \mathrm{~m}$ vào trong rùng và biến mất trong khoảng 1,5 - 2 tháng sau bão do tác động của sóng và dòng triều.
\end{abstract}

\section{MỞ ĐÀ̀U}

Hải Phòng là thành phố biển, có đường bờ biển dài $125 \mathrm{~km}$, quanh năm luôn phải đối mặt với các tác động tiêu cực của thiên tai như sóng gió lớn, áp thấp nhiệt đới, bão, nước dâng trong bão và thuỷ triều dâng cao. Sóng, bão và gió lớn thường gây xói lở bờ biển, không chỉ trực tiếp làm mất đất đai, đe dọa trực tiếp cuộc sống của dân cư ven biển và ảnh hưởng đến các hoạt động kinh tế, mà còn tác động đến môi trường như làm giảm diện tích rừng ngập mặn (RNM) (Trần Đức Thạnh và cộng sự, 2000). Thậm chí bão lớn còn cuốn theo một lượng lớn bùn cát gây sa bồi luồng bến, vùi lấp và làm giảm đa dạng sinh học vùng triều. Cơn bão như cơn bão số 2 đổ bộ ngày 31/07/2005 có tên Quốc tế là Washi đã làm thiệt hại 218 tỉ đồng ở Hải Phòng. Riêng huyện Tiên Lãng có gần 1200 ha nuôi trồng thủy sản bị ngập, gần 1000 tấn thủy sản bị mất trắng. Rừng ngập mặn chắn sóng phải mất gần hai tháng sau mới phục hồi lại được.

Vai trò chắn sóng phòng hộ bảo vệ bờ biển và đê biển của rừng ngập mặn đã được khẳng định qua nhiều nghiên cứu của Phan Nguyên Hồng và cộng sự $(1993,2004)$, 
Nguyễn Hoàng Trí và cộng sự (2000) v.v. Gần đây Mazda, Phan Nguyên Hồng và cộng sự (1997) đã bước đầu nghiên cứu tác động sóng biển qua rừng ngập mặn vào bờ ở mức độ sóng trong điều kiện bình thường. Tuy nhiên do điều kiện khảo sát sóng trong bão hết sức khó khăn, nên chưa có công trình nào khảo sát và nghiên cứu nào về tác động giảm sóng của rừng ngập mặn trong điều kiện có bão ở Việt Nam. Bài báo này trình bày kết quả nghiên cứu về quá trình suy giảm sóng bão vào bờ khi đi qua rừng ngập mặn Đại Hợp (Kiến Thuy, Hải Phòng) trong của cơn bão số 2 ngày 31/7/2005.

\section{II . TÀI LIỆU VÀ PHƯƠNG PHÁP NGHIÊN CÚU}

\section{Tài liệu}

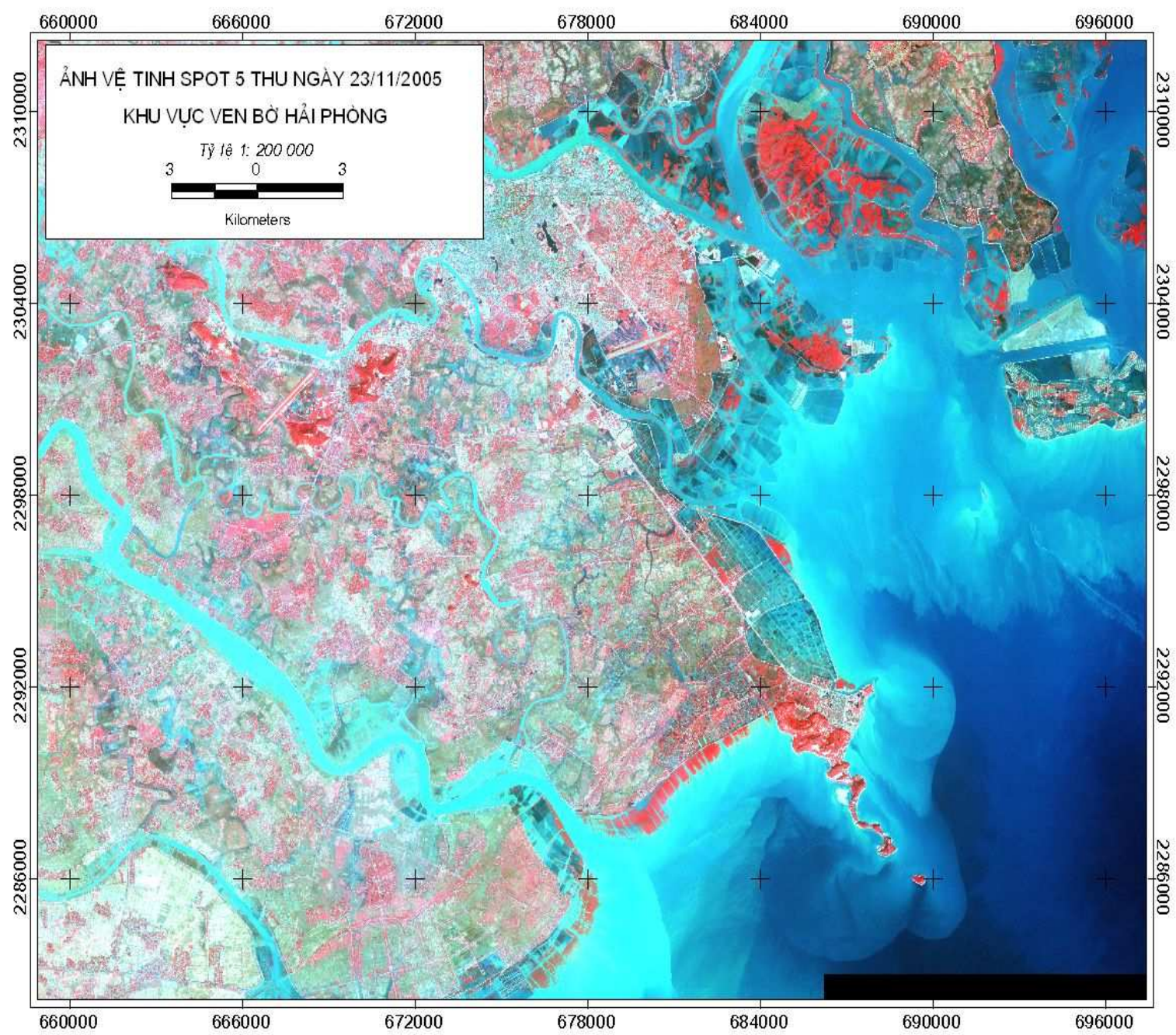

Hình 1: Vị trí điểm khảo sát tại khu vực Đại Hợp (Kiến Thuy, Hải Phòng) 
Tài liệu sử dụng trong nghiên cứu này bao gồm số liệu đo cấu trúc của rừng bần (Sonneratia caseolaris (L.) Engl.) và trang (Kandelia obovata Sheue, Lin \& Yong tại xã Đại Hợp, Huyện Kiến Thụy, thành phố Hải Phòng trong thời gian từ tháng 5 đến tháng 8 năm 2004; số liệu quan trắc sóng trong bão ngày 31/07/2005 và các tài liệu khác có liên quan đến điều kiện sinh thái rừng ngập mặn và động lực bờ khu vực.

\section{Phương pháp}

\section{a. Nghiên cúu cấu trúc rùng}

Nghiên cứu cấu trúc của rừng dựa trên phương pháp của Braun - Blanquet (1932). Rừng bần, trang, trang - bần được nghiên cứu ở độ tuổi 5 - 6 tuổi, nơi có độ rộng dải rừng là $670 \mathrm{~m}$. Tất cả các ô tiêu chuẩn được thực hiện dọc theo mặt cắt vuông góc với đê biển: rừng bần đo 3 ô. Mỗi 1 ô có diện tích $1500 \mathrm{~m}^{2}(25 \mathrm{~m} \mathrm{x} 60 \mathrm{~m})$; rừng trang đo 3 ô. Mỗi 1 ô có diện tích $100 \mathrm{~m}^{2}(10 \mathrm{~m}$ x $10 \mathrm{~m})$.

Đường kính thân cây bần được đo từ mặt bãi đến độ cao $80 \mathrm{~cm}$. Đường kính thân cây trang được đo trên cổ bạnh gốc, vì bạnh gốc là phần phát triển từ trụ mầm, có nhiều lỗ vỏ và vết nứt có tác dụng trực tiếp nhận không khí được xem như là rễ hô hấp của cây.

Theo các quy tắc xác suất thống kê (Phạm Văn Kiều, 1996), độ che phủ của cây được xác định bằng cách đo đường kính của tán lá lớn nhất và nhỏ nhất. Từ đường kính của tán lá, tính được tỷ lệ che phủ của tán lá:

$$
\mathrm{L}=\frac{\mathrm{S}}{\mathrm{G}} \quad \text { Trong đó: }
$$

S: diện tích đất được che phủ, đơn vị tính là $\mathrm{m}^{2}$.

G: diện tích trên nền đất.

\section{b. Quan trắc sóng}

Trong cơn bão số 2, việc đo sóng ở RNM tại xã Đại Hợp được tiến hành tại 2 vị trí: phía trước RNM khoảng $150 \mathrm{~m}$ và chân bờ đê (phía sau $\mathrm{RNM}$ ). Thời gian đo sóng là từ $10 \mathrm{~h} 00$ đến $14 \mathrm{~h} 00$ với chu kỳ đo lặp lại 15 phút. Sóng bão được đo bằng máy IVANOP H10 kết hợp với cột thuỷ chuẩn (MIA) đặt tại điểm đo cách bờ sóng vỗ ra phía ngoài biển là $2 \mathrm{~m}$.

Phương pháp tính suy giảm sóng qua rừng ngập mặn được dựa theo Massel $\mathrm{S}$. (1999):

- Hệ số suy giảm của độ cao sóng được tính theo công thức: $\mathrm{R}=\frac{\mathrm{H}_{\mathrm{S}}-\mathrm{H}_{\mathrm{L}}}{\mathrm{H}_{\mathrm{S}}}$ 
Trong đó:

$\mathrm{H}_{\mathrm{S}}$ : Độ cao của sóng trước rừng (Điểm thả phao).

$\mathrm{H}_{\mathrm{L}}$ : Độ cao của sóng tại điểm gần sát bờ.

- Năng lượng sóng được tính theo công thức : $E=\frac{1}{8} \rho g H^{2} L$

Trong đó:

$\mathrm{g}$ : gia tốc trọng trường.

$\rho:$ là tỉ trọng của nước.

H: độ cao sóng.

L: độ dài bước sóng.

\section{c. Khảo sát gò̀ bùn cát}

Sau bão khi nước rút qua rừng, tiến hành đo độ cao của gờ cát bùn do sóng vun tụ và bị rừng ngăn cản lại tại bìa rừng.

\section{KẾT QUẢ VÀ THẢO LUẬN}

\section{Cấu trúc của rùng}

\section{a. Thành phần loài và phân bố}

Rừng trang - bần với độ tuổi 5 - 6 tuổi, chiều rộng $670 \mathrm{~m}$ ở phía ngoài đê xóm Đông Tác, xã Đại Hợp, huyện Kiến Thuy, Hải Phòng, nằm sát ngoài đê, cạnh cửa sông Văn Úc, được trồng từ các năm 1999 - 2000. Dải ngoài cùng của rừng là rừng cây bần chua (Sonneratia caseolaris) được trồng năm 2000 rộng $200 \mathrm{~m}$. Tiếp theo về phía lục địa là dải rừng trồng thuần cây trang (Kandelia obovata), rộng $200 \mathrm{~m}$ được trồng trong các năm 1999 - 2000. Dải rừng sát đê hỗn hợp bần trồng xen với trang, có chiều rộng $270 \mathrm{~m}$.

\section{b. Cấu trúc phân tầng}

Từ số liệu đo dạc của thân cây ngập mặn, quần xã thực vật ở đây được chia thành 2 tầng như sau:

Tầng 1: Tầng cây có chiều cao từ 4,03 m - 4,59 m.

Tầng 2: Tầng có cây cao từ 1,63 m - 1,66 m. 
Tại thời điểm khảo sát, tầng cây tái sinh hầu như chưa có mặt. Ngoài ra, trên nền sàn rừng khu vực trồng bần có rễ bần chiều cao trung bình $32 \mathrm{~cm}$, với mật độ 98 rễ/m².

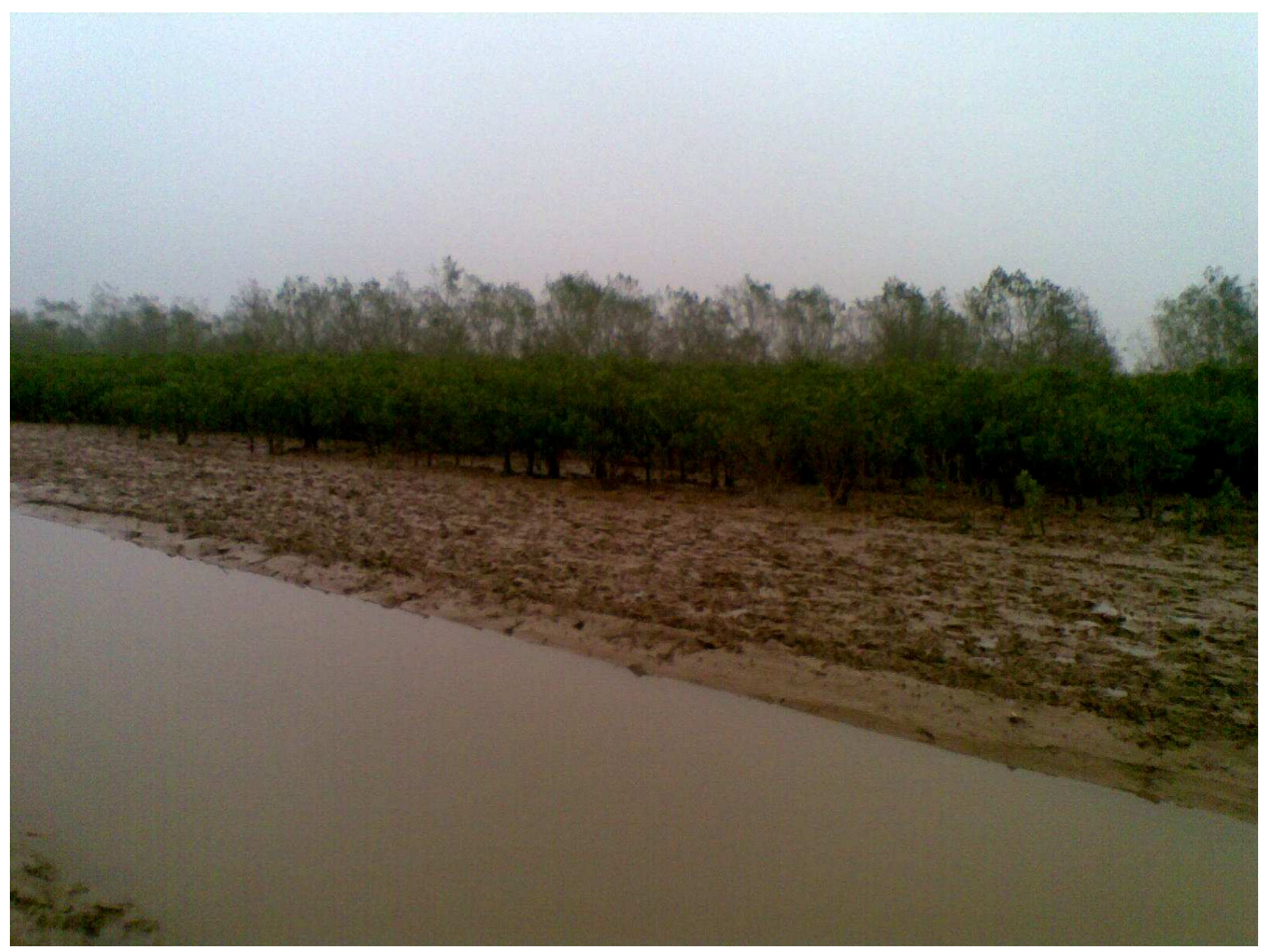

Hình 2: Rừng bần - trang tại Đại Hợp (Kiến Thụy, Hải Phòng

\section{c. Mật độ, số lự̣ng và kích thước cây rùng}

Dải rừng phía biển là rừng bần thuần loài, cây bần cách đều nhau do khi trồng qui định. Trong một ô tiêu chuẩn $25 \mathrm{~m}$ x $60 \mathrm{~m}$ có 203 cây, vì vậy mật độ cây của dải rừng này là 1351 cây/ha (bảng 1). Tầng tán cách gốc cây từ dưới mặt đất lên đồng đều khoảng 70 $90 \mathrm{~cm}$. Tại khu vực này, tốc độ tăng trưởng của cây khá lớn so với các khu vực lân cận. Rừng tương đối đồng đều về về kích thước thân và chiều cao thân cây: đường kính thân tập trung hơn trong khoảng 100 - 150 mm và chiều cao cây ưu thế trong nhóm 400 - 500 cm (bảng 2). 
Bảng 1: Mật độ và kích thước cây ở dải rừng bần ở phía biển

\begin{tabular}{|c|c|}
\hline Các chỉ tiêu & Bần (Sonneratia caseolaris $)$ \\
\hline Số lượng cây/1 ô nghiên cứu & 203 \\
\hline Số lượng cây/ha & 1351 \\
\hline Đường kính thân lớn nhất $(\mathrm{mm})$ & 200 \\
\hline Đường kính thân trung bình $(\mathrm{mm})$ & 149,5 \\
\hline Chiều cao thân lớn nhất $(\mathrm{cm})$ & 520 \\
\hline Chiều cao thân trung bình $(\mathrm{cm})$ & 459,01 \\
\hline
\end{tabular}

Bảng 2: Phân bố đường kính và chiều cao thân cây trong ô tiêu chuẩn ở dải rừng bần phía biển

\begin{tabular}{|c|c|c|c|}
\hline & Phân nhóm & Số lượng cây & \% \\
\hline \multirow{2}{*}{$\begin{array}{c}\text { Đường kính thân } \\
(\mathrm{mm})\end{array}$} & $100-150$ & 114 & 56,16 \\
\cline { 2 - 4 } & $>150$ & 89 & 43,84 \\
\hline \multirow{3}{*}{ Chiều cao thân cây $(\mathrm{cm})$} & $<300$ & 3 & 1,5 \\
\cline { 2 - 4 } & $300-399$ & 15 & 7,5 \\
\cline { 2 - 4 } & $400-500$ & 172 & 86,0 \\
\cline { 2 - 4 } & $>500$ & 13 & 6,5 \\
\hline
\end{tabular}

Dải rừng thuần trang nằm sát phía trong rừng bần có mật độ $0,7 \mathrm{~m} \times 0,70 \mathrm{~m}$, tán lá phát triển tốt đều và phân cành cách gốc cây từ mặt bãi từ khoảng $40 \mathrm{~cm}$ trở lên. Trong một ô tiêu chuẩn có 161 cây, mật độ của dải rừng là 16100 cây/ha. Đường kính thân lớn nhất là $121 \mathrm{~mm}$, tập trung trong khoảng $80-100 \mathrm{~mm}$ và trung bình là $9,06 \mathrm{~cm}$. Chiều cao thân cây chủ yếu dưới $180 \mathrm{~cm}$, cao nhất là $185 \mathrm{~cm}$ và trung bình là $165,4 \mathrm{~cm}$ (bảng 3 và 4). 
Bảng 3: Mật độ và kích thước cây ở dải rừng trang nằm giữa

\begin{tabular}{|c|c|}
\hline Các chỉ tiêu & Trang (Kandelia obovata) \\
\hline Số lượng cây/1 ô nghiên cứu & 161 \\
\hline Số lượng cây/ha & 16100 \\
\hline Đường kính thân lớn nhất $(\mathrm{mm})$ & 121 \\
\hline Đường kính thân trung bình $(\mathrm{mm})$ & 90,6 \\
\hline Chiều cao thân lớn nhất $(\mathrm{cm})$ & 185 \\
\hline Chiều cao thân trung bình $(\mathrm{cm})$ & 165,4 \\
\hline
\end{tabular}

Bảng 4: Phân nhóm đường kính và chiều cao các cây trong ô tiêu chuẩn ở rừng trang rộng 670m tại xã Đại Hợp-Kiến Thuỵ

\begin{tabular}{|c|c|c|c|}
\hline \multirow{3}{*}{$\begin{array}{c}\text { Đường kính thân } \\
(\mathrm{mm})\end{array}$} & Phân nhóm & Số lượng cây & $\%$ \\
\cline { 2 - 4 } & dưới 65 & 6 & 3,8 \\
\cline { 2 - 4 } & $65-79$ & 22 & 13,92 \\
\cline { 2 - 4 } & $80-100$ & 122 & 77,22 \\
\hline \multirow{2}{*}{ Chiều cao thân cây $(\mathrm{cm})$} & trên 100 & 22 & 13,92 \\
\cline { 2 - 4 } & dưới 180 & 156 & 38,73 \\
\hline
\end{tabular}

Tại dải rừng hỗn hợp bần - trang ở phía giáp đê biển, cây bần có chiều cao (lớn nhất $410 \mathrm{~cm}$, trung bình $403 \mathrm{~cm}$ ), cao hơn hẳn so với cây trang (cao nhất $190 \mathrm{~cm}$, trung bình $162,5 \mathrm{~cm}$ ). Tuy nhiên, số lương cây trang lại chiếm đại đa số với tỷ lệ 95,6\%, còn bần chỉ chiếm 4,4\% (bảng 5).

Như vậy cùng trồng gần như một thời điểm (bần trồng sau trang 5 tháng) song chiều cao và đường kính cây bần lại lớn hơn so với cây trang theo tỷ lệ chiều cao bần/trang là $410 \mathrm{~cm} / 190 \mathrm{~cm}$. Đường kính thân bần/trang là $156 \mathrm{~mm} / 91 \mathrm{~mm}$. Nguyên nhân chính là do sự khác nhau về đặc điểm và tốc độ sinh trưởng của hai loài và một phần do đặc điểm môi trường và thổ nhưỡng vùng cửa sông phù hợp cho sự phát triển của cây bần hơn so với cây trang. 
Bảng 5: Mật độ và kích thước cây ở dải rừng hỗn hợp bần - trang ở phía giáp đê biển

\begin{tabular}{|l|c|c|c|}
\hline \multicolumn{1}{|c|}{ Các chỉ tiêu } & Bần & Trang & Tổng số \\
\hline Số cây/ô nghiên cứu theo trang & 6,13 & 144 & 150,13 \\
\hline Tỷ lệ \% & 4,4 & 95,6 & 100,00 \\
\hline Số lượng cây/ha & 613 & 14400 & 15013 \\
\hline Đường kính thân lớn nhất (mm) & 156 & 91 & - \\
\hline Đường kính thân trung bình (mm) & 110,85 & 76,54 & - \\
\hline Chiều cao cây lớn nhất $(\mathrm{cm})$ & 410 & 190 & - \\
\hline Chiều cao cây trung bình $(\mathrm{cm})$ & 403 & 162,5 & - \\
\hline
\end{tabular}

\section{d. Mức độ che phủ tán lá của rùng}

Dải rừng bần phía biển độ rộng $200 \mathrm{~m}$ có mật độ $3 \mathrm{~m}$ x $3 \mathrm{~m} / \mathrm{cây}$, khoảng cách đồng đều và tỉ lệ che phủ đạt $93 \%$. Dải rừng trang nằm giữa có mật độ $0,7 \mathrm{mx} 0,7 \mathrm{~m} /$ cây, cũng có khoảng cách khá đồng đều, rừng chưa khép tán và tỉ lệ che phủ đạt $92 \%$. Tại dải rừng hỗn hợp bần trang nằm sát đê biển, mật độ cây là $0,7 \mathrm{~m}$ x $0,7 \mathrm{~m}$, khoảng cách các cây khá đều, rừng chưa khép tán và tỉ lệ che phủ đạt $90 \%$.

\section{Mức độ giảm sóng bão khi qua rừng ngập mặn và sự hình thành các gờ cát}

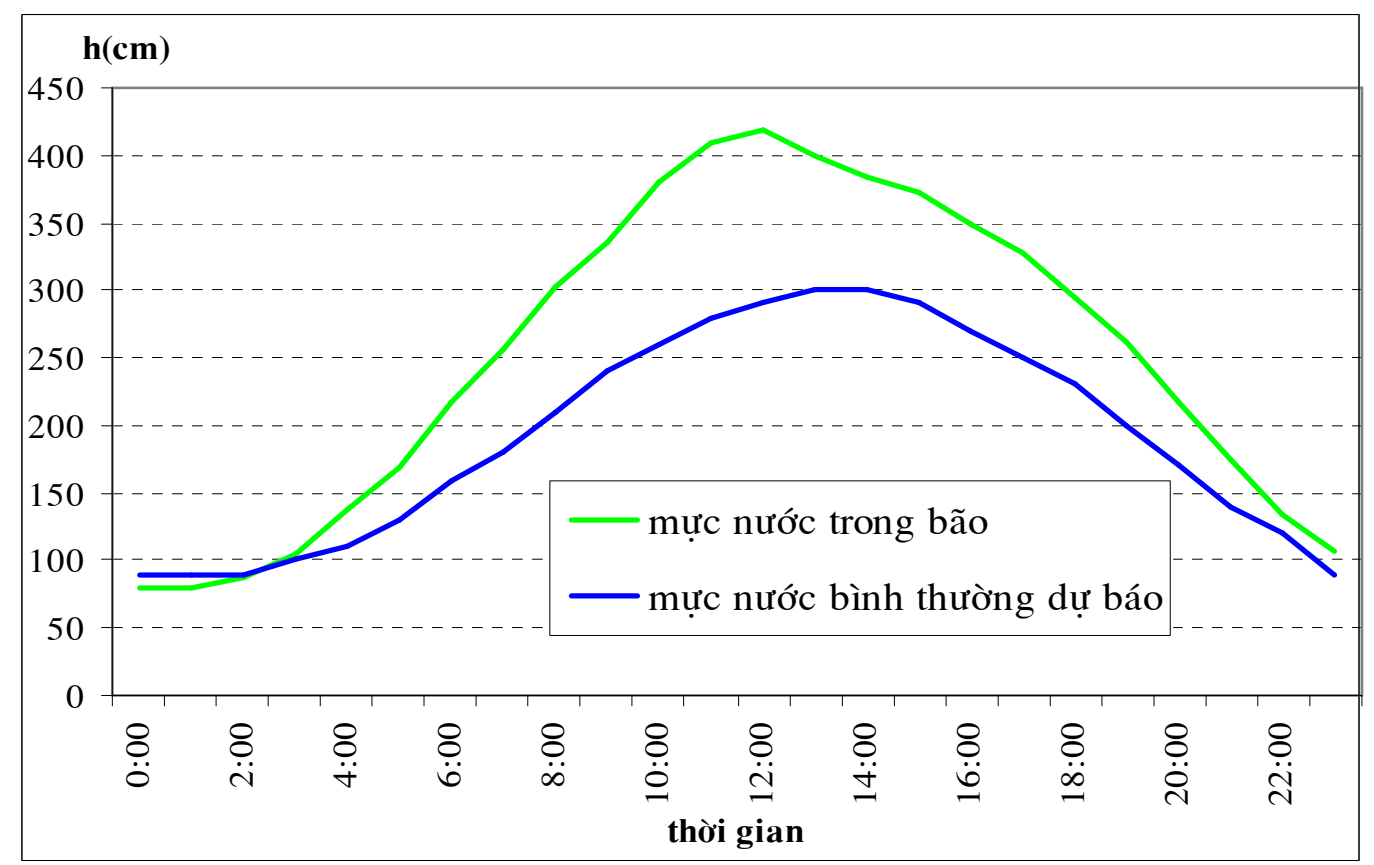

Hình 3: Mực nước dâng do bão số 2 ngày 31/7/2005 tại khu vực Đại Hợp 


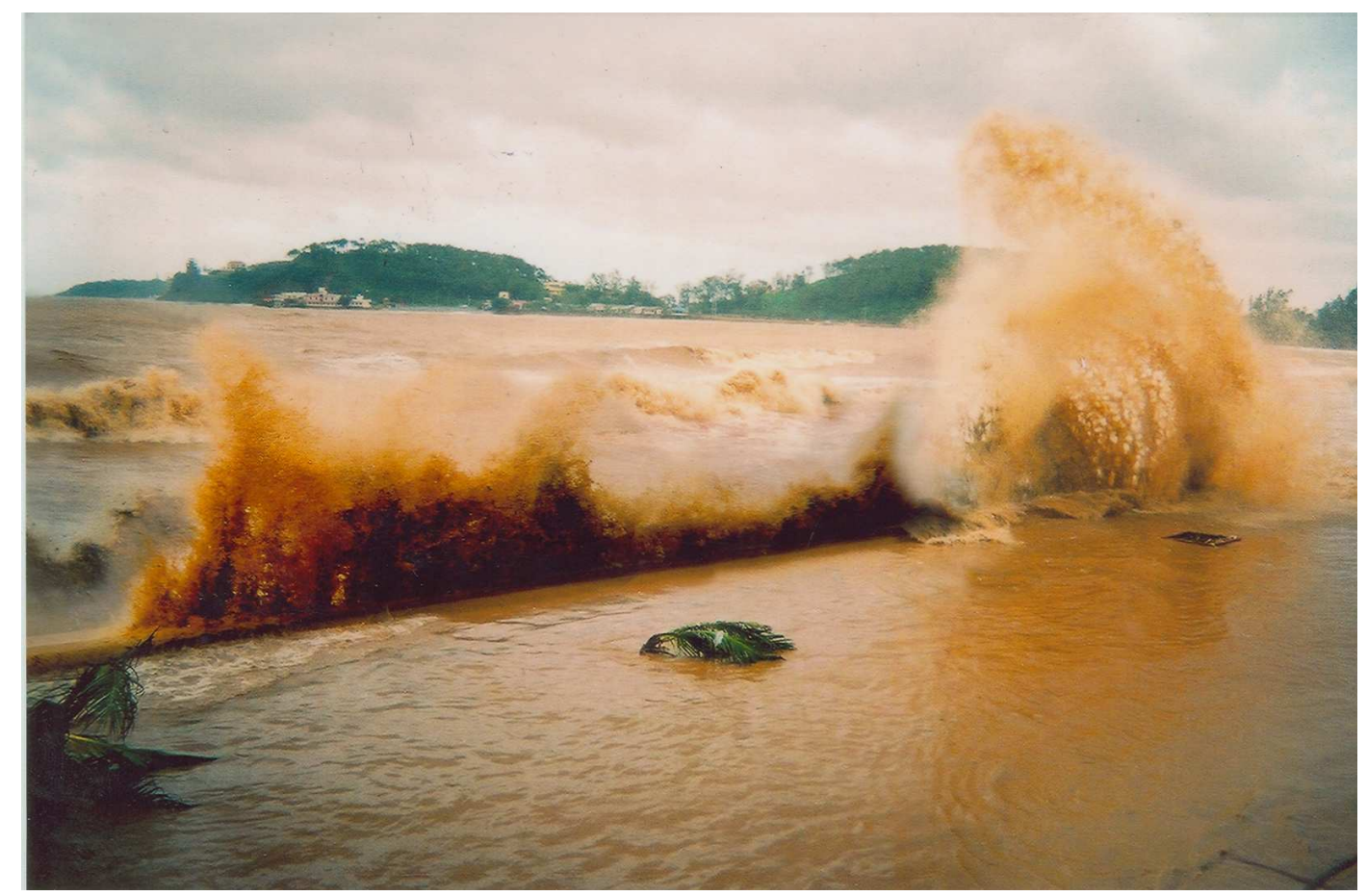

Hình 4: Sóng vỗ bờ Đồ Sơn trong cơn bão số 2 - 2005 đổ bộ vào Hải Phòng

Khu vực bờ biển Bàng La - Đại Hợp suốt thời gian dài 1930 - 1990 bị xói lở mạnh và rất mạnh với tốc độ trung bình $11-13 \mathrm{~m} /$ năm trên chiều dài 7,2 - 7,5 km. Bắt đầu từ khảng năm 1990 trở về sau, bờ và bãi triều ổn định và chuyển dần sang bồi tụ. Mặc dù vậy, khi có bão, bờ đê Bàng La vẫn là nơi xung yếu và có khả năng bị vỡ sạt khi có bão, triều cường ((Trần Đức Thạnh và cộng sự, 2000). Chính sự phát triển của rừng ngập mặn trồng đã góp phần quan trọng bảo vệ và ổn định đê ke khu vực này.

Cơn bão số 2 ngày 31/7/2005 đổ bộ vào ven biển Hải Phòng trong khoảng thời gian từ $8 \mathrm{~h}$ đến $13 \mathrm{~h}$ với hướng gió thay đổi liên tục. Độ cao sóng gần Hòn Dáu lớn nhất là $3,6 \mathrm{~m}$. Mực nước thực tế dâng cao nhất là 4,26m lúc $11 \mathrm{~h} 30$ phút (trạm KTTV Hòn Dáu), trong khi dự báo thuỷ triều mực nước cường là 2,9m (Bộ tư lệnh Hải quân, 2005; Trung tâm khí tượng thuỷ văn biển, 2005) (hình 3).

\section{a. Tác động giảm độ cao sóng của rùng ngập mặn tại Đại Hộp}

Độ cao sóng bão phía trước rừng quan trắc được có giá trị lớn nhất $1,5 \mathrm{~m}$, nhỏ nhất $1,0 \mathrm{~m}$ và trung bình $1,3 \mathrm{~m}$. Sau khi vuợt qua dải rừng rộng $670 \mathrm{~m}$, độ cao sóng đã giảm xuống đáng kể với giá trị lớn nhất $0,32 \mathrm{~m}$, nhỏ nhất $0,23 \mathrm{~m}$ và trung bình $0,27 \mathrm{~m}$. Hệ số suy giảm độ cao sóng trung bình trong thời gian quan trắc qua dải rừng này lớn nhất $83 \%$, nhỏ $75 \%$ và trung bình $79 \%$ (bảng 6 ). Độ cao sóng trước rừng càng lớn thì hệ số suy giảm 
độ cao sóng qua rừng càng lớn. Trong điều kiện không có rừng ngập mặn che chắn, sóng vỗ bờ rất mạnh và gây phá hỷ bờ biển nghiêm trọng nhiều nơi tại Hải Phòng (hình 4).

Bảng 6: Độ cao sóng và hệ số suy giảm độ cao sóng RNM tại xã Đại Hợp (cơn bão số 2 ngày $31 / 7 / 2005$ )

\begin{tabular}{|c|c|c|c|}
\hline \multirow{2}{*}{ Thò̀i gian } & \multicolumn{2}{|c|}{ Độ cao sóng (m) } & \multirow{2}{*}{$\begin{array}{l}\text { Hệ số suy giảm } \\
\text { độ cao sóng (\%) }\end{array}$} \\
\hline & Trước rù̀ng & Sau rù̀ng & \\
\hline 10:00:00 & 1,0 & 0,25 & 75 \\
\hline 10:30:00 & 1,2 & 0,28 & 77 \\
\hline $10: 45: 00$ & 1,2 & 0,3 & 75 \\
\hline 11:00:00 & 1,3 & 0,3 & 77 \\
\hline 11:30:00 & 1,35 & 0,32 & 76 \\
\hline 11:45:00 & 1,35 & 0,25 & 81 \\
\hline 12:00:00 & 1,4 & 0,28 & 80 \\
\hline $12: 15: 00$ & 1,35 & 0,26 & 81 \\
\hline 12:30:00 & 1,2 & 0,27 & 78 \\
\hline $12: 45: 00$ & 1,3 & 0,25 & 81 \\
\hline 13:00:00 & 1,5 & 0,25 & 83 \\
\hline 13:30:00 & 1,4 & 0,27 & 81 \\
\hline $13: 45: 00$ & 1,35 & 0,23 & 83 \\
\hline 14:00:00 & 1,3 & 0,23 & 82 \\
\hline T.bình & 1,30 & 0,27 & 79 \\
\hline
\end{tabular}

Theo khảo sát và tính toán của Mazda và cộng sự (1997) trong điều kiện thời tiết bình thường, ở Thái Thụy, Thái Bình sóng có chu kỳ 5 - 8 giây khi vượt qua dải RNM rộng $100 \mathrm{~m}$, khi vào sát bờ độ cao giảm $20 \%$. Sóng có độ cao $1 \mathrm{~m}$ khi vượt qua dải $\mathrm{RNM}$ 6 năm tuổi, rộng $1,5 \mathrm{~km}$ khi vào đến bờ chỉ còn độ cao $0,05 \mathrm{~m}$. So sánh một cách tương đối kết quả khảo sát và tính toán của chúng tôi với kết quả của các tác giả nói trên, có thể nói rằng trong cùng một điều kiện tương tự nhau, hệ số giảm sóng của rừng ngập mặn trong điều kiện sóng bão lớn hơn điều kiện sóng bình thường nhiều. 
Bên cạnh suy giảm độ cao sóng, năng lượng sóng qua rừng ngập mặn cũng suy giảm nhiều lần. Kết quả tính năng lượng trung bình sóng trong cơn bão số 2 khi qua dải rừng ngập mặn như sau: trước rừng sóng cao $\mathrm{H}=1,3 \mathrm{~m}$; năng lượng sóng $\mathrm{E}=212.306 \mathrm{~N} / \mathrm{m}^{2}$; sau rừng sóng cao $\mathrm{H}=0,27 \mathrm{~m}$; năng lượng sóng $\mathrm{E}=9.158 \mathrm{~N} / \mathrm{m}^{2}$.

\section{b. Cát tạo thành gò̀ cát bùn do tác dụng của rùng chắn.}

Ngoài vai trò ngăn cản làm giảm độ cao sóng và năng lượng sóng phá hủy bờ, RNM ở đây còn có tác dụng là cản không cho lượng bùn cát dồn mạnh vào bờ gây lấp cây cối, làm giảm độ tàn phá của bão và những tác động môi trường sau khi hết bão.

Sau khi bão tan, chúng tôi đã tiến hành đo được độ cao lượng cát bùn tạo thành gờ cát bùn tại rừng bần ngoài cùng với chiều sâu vào rừng là $55 \mathrm{~m}-58 \mathrm{~m}$. Tại đây sóng đã dồn tụ tạo thành $2-3$ gờ cát bùn chạy song song với đường bờ, mỗi gờ rộng chừng 35 $40 \mathrm{~cm}$, độ cao tới $35 \mathrm{~cm}$. Rễ thở của cây bần khu vực này bị vùi lấp gần hết. Theo dõi tiếp tục hơn 1,5 tháng sau, chúng tôi thấy những gờ cát bùn này bị nước triều lên xuống bào mòn và làm tan hết. Cát bùn của các gờ được sóng xô dải tràn đều khắp nền rừng và dấu vết gờ cát bùn chỉ còn lại mờ nhạt. Do tác động của các gờ cát bùn, khu vực RNM bị tổn thương là dải rộng $55-60 \mathrm{~m}$ tính từ bìa ngoài rừng, đặc biệt $15-20 \mathrm{~m}$ sát bìa rừng và chỉ sau gần 2 tháng sau bão mới dần trở về được gần với trạng thái ban đầu.

\section{KẾT LUẬN}

Nhờ có dải rừng ngập mặn bần - trang rộng $670 \mathrm{~m}$ có độ tuổi khoảng 5 - 6 năm tại khu vực Đại Hợp (Kiến Thuỵ, Hải Phòng), đo độ cao của sóng trong cơn bão số 2 ngày $31 / 7 / 2005$ có độ cao $1,0-1,5 \mathrm{~m}$ trước rừng bị giảm xuống chỉ còn $0,2 \mathrm{~m}-0,32 \mathrm{~m}$ sau rừng sát đê biển với hệ số suy giảm $75-83 \%$, trung bình $79 \%$. Tương ứng, năng lượng sóng trước rừng trung bình $212.306 \mathrm{~N} / \mathrm{m}^{2}$ ứng với độ cao sóng trung bình $1,3 \mathrm{~m}$ chỉ còn 9.158 $\mathrm{N} / \mathrm{m}^{2}$ sau rừng ứng với độ cao sóng trung bình $0,27 \mathrm{~m}$. So sánh với một số ít kết quả khảo sát đã có, có thể thấy hệ số giảm sóng của rừng ngập mặn trong điều kiện sóng bão lớn hơn điều kiện sóng bình thường nhiều.

Sóng đã vun tụ tạo nên các gờ bùn cát chạy song song với đường bờ lấn từ bìa ngoài rừng vào sâu trong rừng $55-60 \mathrm{~m}$ thì bị $\mathrm{RNM}$ cản lại. Nhờ đó, bùn cát không bị tràn vào bờ để gây nên một số tác động tiêu cực về môi trường. Do tác động của thuỷ triều và sóng xô, trong vòng 1,5 tháng sau bão, các gờ cát này biến mất. 


\title{
TÀI LIỆU THAM KHẢO
}

1. Braun - Blanquet J., 1932. Plant Sociology: the study of plant communities. Mc Graw - Hill, New York, 439P.

2. Bộ tư lệnh Hải quân, 2005. Bảng thuỷ triều. Tập 1, NXB Quân đội nhân dân.

3. Trung tâm khí tượng thuỷ văn biển, 2005. Bảng thuỷ triều. NXB Thống kê, Hà Nội.

4. Phan Nguyen Hong, Hoang Thị San, 1993. Mangroves of Vietnam. IUCN, Bangkok, Thailand, 173p.

5. Phan Nguyên Hồng (chủ biển), 2004. Hệ sinh thái rừng ngập mặn vùng ven biển đồng bằng sông Hồng. NXB Nông nghiệp. Hà Nội. 337 trang.

6. Mazda, Y. Hong P.N. et al, 1997. Mangroves as a coastal protection from waves in the Tong King delta, Vietnam. Mangroves and salt marshes, 1. Kluwer Academic Publisher. Printed in the Nertherlands: 127-135.

7. Massel S., 1999. Surface wave propagation in mangrove forests. Fluid Dyanmics Research. 24: 219-249.

8. Trần Đức Thạnh, Nguyễn Đức Cự và nnk, 2000. Nghiên cứu dự báo, phòng chống sạt lở bờ biển Bắc bộ từ Quảng Ninh đến Thanh Hóa. Báo cáo tổng kết dự án cấp Nhà nước KHCN - 5A. Lưu trữ tại Trung tâm TT KHCNQG, Hà Nội.

9. Phạm Văn Kiều, 1996. Lý thuyết xác suất thống kê toán học. Trường ĐHSP, ĐHQG Hà Nội: 217-225.

10. Nguyen Hoang Tri, Nguyen Huu Tho, 2000. Community participation in rehabilitation, conservation and management of mangroves in the Red River Delta. In Proc. Workshop: Management and Sustainable use of Natural Resources and Environment in Coastal Wetlands. Hanoi 1-3 Nov. 1999: 208-216.

\section{THE ROLE OF MANGROVES FOR REDUCING HIGH WAVES DURING TYPHOON IN DAI HOP (KIEN THUY, HAI PHONG)}

\author{
VU DOAN THAI
}

Summary: The mangroves in Dai Hop common (Kien Thuy district, Hai Phong City) were planted from 1999 - 2000 and about 5 - 6 year old at the surveying time. By the bank of 
$670 m$ wide, they are closed to sea dike and composed of two species such as Sonneratia caseolaris (L.) Engl and Kandelia obovata Shuen Liu \& Gong. With density of 1,351 trees/ha and coverage of $93 \%$, the Sonneratia caseolaris were in average size of $459 \mathrm{~cm}$ tall and $149.5 \mathrm{~mm}$. The corresponding parameters of Kandelia obovata were of 16,100 trees/ha in density, $92 \%$ in coverage, $165.5 \mathrm{~cm}$ tall and $90.6 \mathrm{~mm}$ in diameter.

Attacking the studied area on 31st, July 2007, the typhoon No.2 (Washi) created the wave from $1.0-1.2 \mathrm{~m}$ high with mean energy of $212.306 \mathrm{~N} / \mathrm{m}^{2}$ at the seaward edge of mangrove forest. After passing the forest, the wave height was reduced to $0.2 \mathrm{~m}-0.32 \mathrm{~m}$ with mean energy of $9.158 \mathrm{~N} / \mathrm{m}^{2}$, and accordingly the reduced coefficient of wave from $75-83 \%$, average of 79\%. Besides reducing wave height and energy, mangroves had the role of preventing the muddy sand ridges which were formed and pushed landwards by storm wave. These muddy sand ridges were of $35 \mathrm{~cm}$ high and from $35-40 \mathrm{~cm}$ wide, penetrated into mangroves from $55-60 \mathrm{~m}$, and disappeared after typhoon from $1.5-2.0$ months by the wave and tidal current.

Ngày nhận bài: 05 - 02 - 2011

Nguoòi nhận xét: PGS. TS. Trần Đức Thạnh 